\title{
Meningioma in mediastinum - a case report with review of the literature
}

\author{
Xiuling Wang ${ }^{1}$, Yin Wang ${ }^{2}$, Weiqiang Zheng ${ }^{3}$ \\ 1. Department of Pathology, Shanghai 7th People's Hospital, Shanghai, China. 2. Department of Neuropathology, \\ Huashan Hospital, FuDan University, Shanghai, China. 3. Department of Pathology, Changhai Hospital, Second Military \\ Medical University, Shanghai, China
}

Correspondence: Weiqiang Zheng. Address: Department of Pathology, Changhai Hospital, 168 Changhai Road, Shanghai 200433, China. Telephone: 86-213-116-2631.Email: zheng6947@126.com

Received: J une 23, 2012

Accepted: August 9, 2012

Published: October 1, 2012

DOI : $10.5430 /$ jst.v2n5p29

URL: http://dx.doi.org/10.5430/jst.v2n5p29

\begin{abstract}
A rare case of meningioma in mediastinum occurring at a 53-year-old Chinese man was reported. He was found a mass in the upper right mediastinum by chest X-ray examination without any symptom. The mass showed nodular and ovoid shape with complete capsule. Microscopically it was composed of sheets of larger plump cells and bundles of spindle cells arranged in fasciculars or whorl patterns. Immunohistochemically the neoplastic cells were positive for vimentin and EMA. This is an extremely rare tumor in this region of mediastinum and the differential diagnoses were discussed.
\end{abstract}

\section{Key words}

Meningioma, Mediastinal, Ectopic

\section{Introduction}

Primary ectopic meningiomas of mediastinum are exceedingly rare, and are usually benign, slow growing tumors. The histogenesis of ectopic meningiomas is not confirmed yet. Only a few cases of mediastinal primary ectopic meningiomas have been described in the literature ${ }^{[1-4]}$ (Table 1 ), in which only a case was malignant. The aim of the current study is to discuss the pathology of ectopic meningioma occurring in mediastinum, with its histochemical and immunohistochemical profile and the differential diagnosis of this rare entity.

\section{Case presentation}

A 53-year-old Chinese man, who was a teacher at a middle school, was found a mass in the upper right mediastinum by chest X-ray examination without any symptom. The patient did not think there was family history of the disease. Computed tomography (CT) scan revealed an ovoid mass sized about $9.5 \mathrm{~cm}$ in its greatest dimension in the upper-right mediastinum with moderate or mixed lower to moderate density area (Figure 1). The patient was admitted to the Shanghai 7th People's hospital three weeks ago. Routine laboratory tests did not show any abnormal findings. During the operation, the mass was exposed located in the upper mediastinum. The mass was connected with intervertebral foramen, and then completely excised. 
Table 1. The published cases of primary ectopic meningiomas

\begin{tabular}{|c|c|c|c|c|c|c|c|c|}
\hline Author & Age & Sex & Presenting symptoms & Signs & Management & $\begin{array}{l}\text { Size } \\
(\mathrm{cm})\end{array}$ & Nature & Other features \\
\hline $\begin{array}{l}\text { Wilson AJ et } \\
\text { al.[1] }\end{array}$ & 63 & M & Horner syndrome & $\begin{array}{l}\text { Mass in the pleural } \\
\text { space }\end{array}$ & Surgical excision & 4 & Benign & \\
\hline $\begin{array}{l}\text { Falleni } \\
\text { et al. [2] }\end{array}$ & 45 & $\mathrm{~F}$ & No & $\begin{array}{l}\text { Mass in the right } \\
\text { mediastinal } \\
\text { paravertebral }\end{array}$ & Surgical excision & 4.5 & Benign & Cystic, hemorrhagic \\
\hline $\begin{array}{l}\text { Palimento D et } \\
\text { al. [3] }\end{array}$ & 45 & $\mathrm{~F}$ & $\begin{array}{l}\text { Left thoracic pain, } \\
\text { dyspnea, fatigability }\end{array}$ & $\begin{array}{l}\text { Mass in the posterior } \\
\text { mediastinum }\end{array}$ & Surgical excision & 12 & Benign & $\begin{array}{l}\text { Spontaneous hemothorax, } \\
\text { necrosis }\end{array}$ \\
\hline $\begin{array}{l}\text { Yang } X \text { et al. } \\
{[4]}\end{array}$ & 41 & M & $\begin{array}{l}\text { Progressive chest, } \\
\text { distress and cough }\end{array}$ & $\begin{array}{l}\text { Mass in the right } \\
\text { anterior mediastinal }\end{array}$ & $\begin{array}{l}\text { Surgical excision, but } \\
\text { a small residural } \\
\text { tumor tissue }\end{array}$ & 12 & malignant & $\begin{array}{l}\text { Invaded the superior and } \\
\text { middle lobe of the right lung } \\
\text { and the wall of superior vena } \\
\text { cava with necrosis }\end{array}$ \\
\hline $\begin{array}{l}\text { Mogi A et al. } \\
\text { [5] }\end{array}$ & 61 & M & $\begin{array}{l}\text { Progressive oppressive } \\
\text { felling in the left } \\
\text { thoracic region }\end{array}$ & $\begin{array}{l}\text { Mass in the left } \\
\text { anterior mediastinal }\end{array}$ & Surgical excision & 9 & $\begin{array}{l}\text { Atypical } \\
\text { meningioma }\end{array}$ & $\begin{array}{l}\text { Involved in the upper lobe of } \\
\text { left lung }\end{array}$ \\
\hline $\begin{array}{l}\text { Present } \\
\text { case[6] }\end{array}$ & 53 & M & No & $\begin{array}{l}\text { Mass in the } \\
\text { upper-right } \\
\text { mediastinum }\end{array}$ & Surgical excision & 9 & Benign & Cystic, hemorrhagic \\
\hline
\end{tabular}

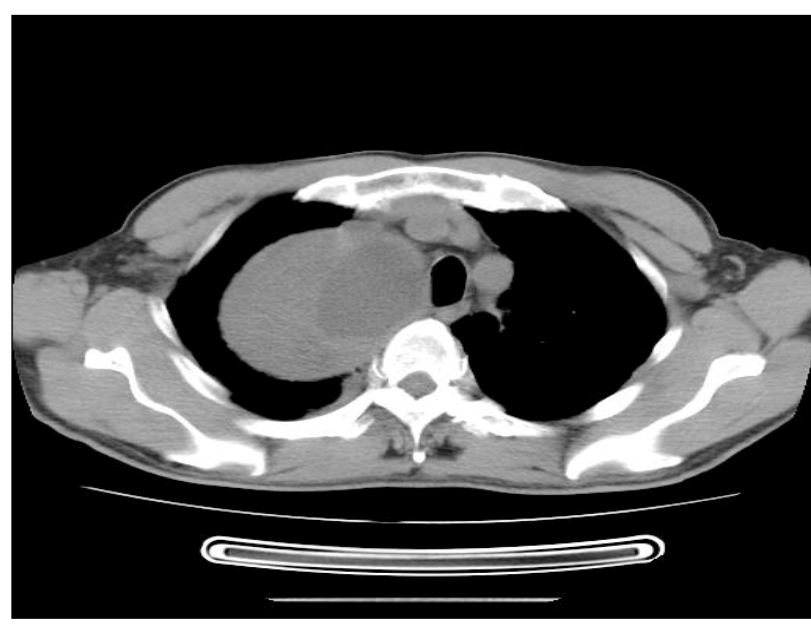

Figure 1. CT scan revealed an ovoid mass in the upperright mediastinum with moderate or mixed lower to moderate density area

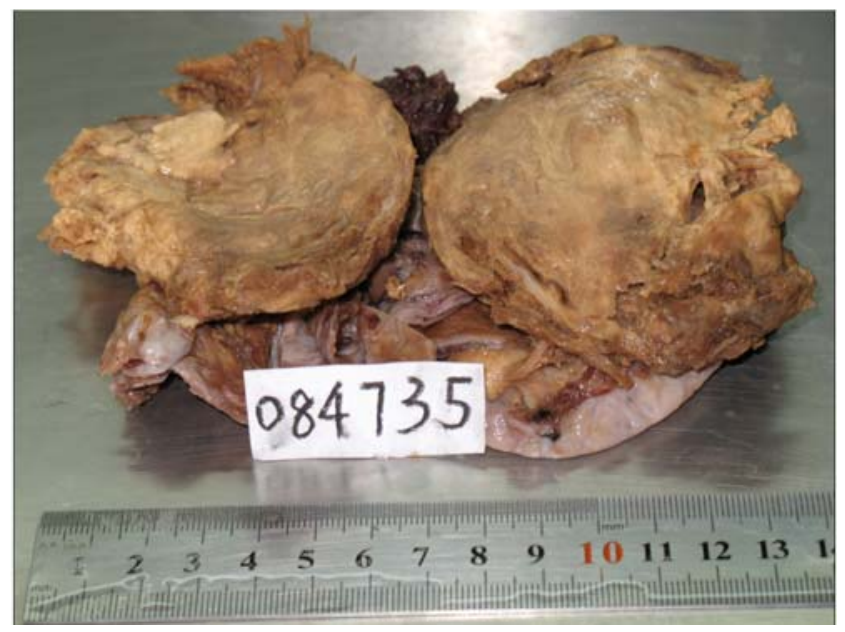

Figure 2. The mass showed nodular and ovoid with complete encapsule

Grossly the mass showed nodular and ovoid shape with complete encapsule, measured approximately $9 \mathrm{~cm}$ in its greatest dimension. Cut surface showed brown-yellow and gray-yellow in color with slightly hard consistency and several cysts $(0.5 \mathrm{~cm} \sim 2 \mathrm{~cm}$ in diameter) (Figure 2).

Microscopically the tumour was composed of sheets of larger plump cells and bundles of spindle cells arranged in fasciculars or whorl patterns (Figure 3).The tumor cells had indistinct cellular borders and weakly eosinophilic cytoplasm. The nuclei were round or oval with delicate chromatin, inconspicuous nucleoli and nuclear pseudoinclusions. Mitotic figures were absent. The prominent fibrous bands with vessels characterized by thick hyalinized walls were shown in the interstitial tissue. Few hemorrhagic and cyst areas were dispersed in the neoplasm with reactive proliferation of histiocytes and infiltration of lymphocytic cells. No cytologic atypia, necrosis or invasion to surrounding structures was observed. Immunohistochemically the neoplastic cells were positive for vimentin, EMA (Figure 4) and locally positive for S-100 protein and CD68. They were negative for CK19, HMB45, CD21, CD35, desmin, GFAP, CD34. The lymphocytes were negative for TdT. 


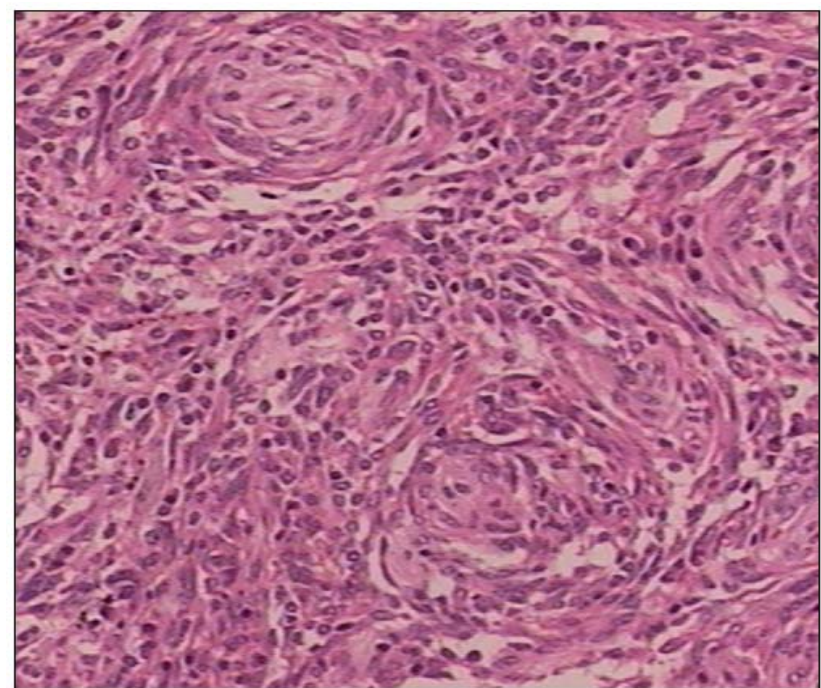

Figure 3. The tumour cells was composed of larger plump cells and of bundles of spindle cells arranged in fasciculars or whorls.(H\&E×200)

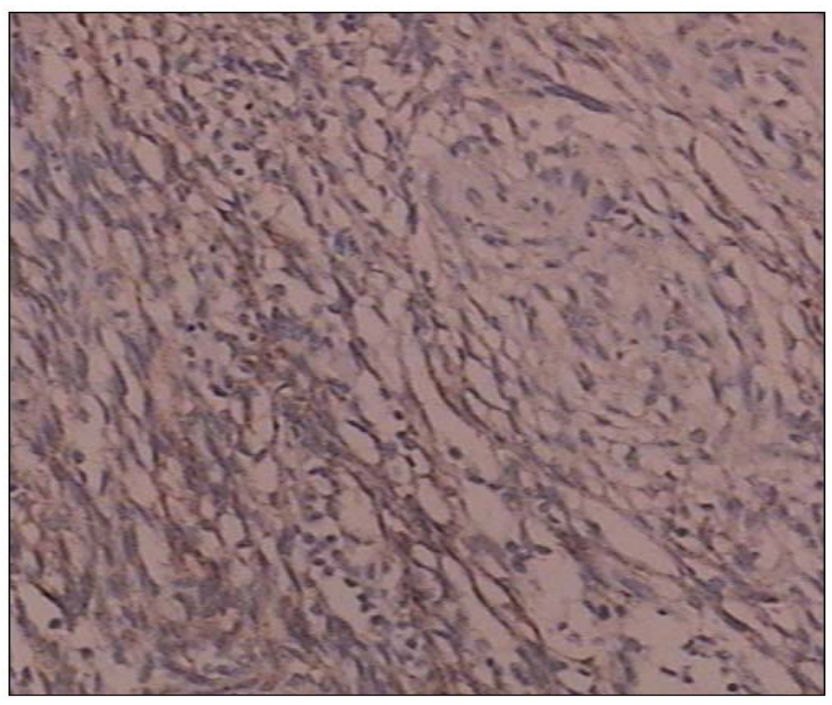

Figure 4. Immunohistochemical staining showed EMA positivity in tumor cells

The postoperative course was uneventful and the patient was discharged ten days after operation. On the 20th day after operation, the patient had magnetic resonance imaging (MRI) of the head and spine, which excluded possible central nervous system lesions. So the pathological diagnosis of primary mediastinal meningioma was made.

\section{Discussion}

Primary ectopic meningiomas of mediastinum are exceedingly rare, and are usually benign, slowly growing tumors. The histogenesis of ectopic meningiomas is still unknown. Only a few cases of mediastinal primary ectopic meningiomas have been described in the literature (Table 1), in which there is only a malignant case. The current patient has survived for six years without any recurrence or metastasis. Meningiomas occurring distant from skull and vertebral fusion lines and without association with peripheral nerves have been thought to arise from ectopic meningothelial cells abnormally displaced during embryonal development. Meningiomas with a close relationship to cranial or peripheral nerves are thought to arise from meningothelial cells sited near their appropriate foramina, in nervous sheaths carried out along peripheral nerves during fetal development or from perineural cells morphologically, functionally and immunohistochemically similar to meningothelial cells. The occurrence of mediastinal meningiomas may be consistent with this latter hypothesis based on description in current case and in literature ${ }^{[1,2]}$.The intraspial and intracranial meningioma may extended to mediastinum, so we must rule out with central nervous system lesions ${ }^{[5,6]}$. Our patient had magnetic resonance imaging of the head and spine, which excluded possible central nervous system lesions.

Despite their unusual site of origin, all ectopic meningiomas described in the literature show morphological, immunohistochemical and ultrastructural features similar to their nervous system counterparts ${ }^{[2,3,7]}$. Most ectopic meningiomas show fibroblastic, meningothelial or transitional morphological features and an immunohistochemically profile with variable immunoreactivity for vimentin, EMA, cytokeratins, S-100, desmoplakins and desmin. This current case was fibroblastic, with whorls architecture and its immunohistochemical staining showed positive for vimentin, EMA and partially positive for S-100 protein, and negative for CK19, HMB45, CD21, CD35, desmin, GFAP, CD34 and CD68, which was accordant with the findings of other reported cases. Ultrastructurally the tumors showed abundant intermediate cytoplasmic filaments, complex interdigitating cell processes and desmosome-like cell junctions. 
The histologic differential diagnoses of this case included those tumors with spindle cells components, they may be as follows: 1) Benign peripheral nerve Schwannoma, a kind of spindle cell tumor with highly cellular areas (Antoni A) and loose spongy areas of lower cellularity (Antoni B), since it usually lacks of distinct whorled architecture and psammoma bodies, and positive for S-100 protein and negative for EMA, making it differs from our case. 2) Spindle cell-type thymoma: It has cyst-like and rosette-like structures, small abortive Hassall's corpuscles, hemangiopericytoma-like pattern and negative staining for EMA, positive staining for CK19 in spindled epithelia and positive staining for TdT in the small lymphocytes. The above findings are not presented in our case. 3) Fibrous histiocytoma: a tumor usually showing a storiform pattern, lacking whorls pattern and the spindle cells, positive staining for vimentin, CD68 and negative for cytokeratin and EMA. So the diagnosis could be excluded in current case. 4) Dendritic cell tumour: It can show whorls pattern and residual small lymphocytes. However, the tumor cells show different immunohistochemical expressions. 5) Inflammatory myofibroblastic tumor: although composed of spindle cells with some Inflammatory cells, expresses different immunophenotypes, most often positive for SMA, desmin, ALK and negative for EMA.

In conclusion, all of the current histologic and immunostaining findings support the diagnosis of meningioma in the mediastinum.

\section{Conflict of interests}

The author declares that there is no conflict of interest statement.

\section{References}

[1] Wilson AJ, Ratliff JL, Lagios MD, Aguilar MJ. Mediastinal meningioma. Am J Surg Pathol. 1979; 3: 557- 62. PMid: 534392 http://dx.doi.org/10.1097/00000478-197912000-00009

[2] Falleni M, Roz E, Dessy E, Del Curto B, Braidotti P, Gianelli U, et al.Primary intrathoracic meningioma: histopathological, immunohistochemical and ultrastructural study of two cases. Virchows Arch. 2001; 439: 196-200. PMid: 11561761 http://dx.doi.org/10.1007/s004280000387

[3] Palimento D, Picchio M. Meningioma of the mediastinum causing spontaneous hemothorax. Ann Thorac Surg. 2006; 81: 1903-4. PMid: 16631706 http://dx.doi.org/10.1016/j.athoracsur.2005.07.045

[4] Yang X, Gao X, Wang S. Primary mediastinal malignant meningioma. Eur J Cardiothorac Surg. 2009; 36: 217-8. PMid : 19410481 http://dx.doi.org/10.1016/j.ejcts.2009.03.040

[5] Mogi A, Hirato J, Kosaka T, Yamaki E, Kuwano H.Primary mediastinal atypical meningioma: report of a case and literature review. World J Surg Oncol. 2012; 10: 17. PMid: 22264362 http://dx.doi.org/10.1186/1477-7819-10-17

[6] Buchfelder M, Nomikos P, Paulus W, Rupprecht H. Spinal-thoracic dumbbell meningioma:a case report. Spine (Phila Pa 1976). 2001; 26: 1500-4. PMid: 11458160

[7] Behbahani M, Ahmad FU, Siddiqui MA, Stewart W, Alakandy LM. Trans jugular extension of meinegioma into the mediastinum-a case report. Acta Neurochir (Wien). 2010; 152: 151-4. PMid: 19399362 http://dx.doi.org/10.1007/s00701-009-0359-5 